\title{
Analysis of Current Account and Real Exchange Rate: Lower Middle Income Countries in Association of Southeast Asian Nations
}

\author{
Hasdi Aimon, Sri Ulfa Sentosa, Anggi Putri Kurniadi
}

\begin{abstract}
The study investigates the simultaneous equation model of the current account and real exchange rates in group of lower middle income in Association of Southeast Asian Nations (ASEAN). This study uses time series from 2000-2017 (18 years) and cross section 6 countries (Indonesia, Philippines, Vietnam, Lao, Myanmar, and Cambodia). There are three important findings in this study; first, for the current account is financial development has positive effect while government spending and foreign direct investment have negative effect; second, for the real exchange rate is economic openness, money supply, and interest rate have positive effect while foreign direct investment and current account have negative effect; third, only current account affects real exchange rates. Therefore, it is highly recommended for group of lower middle income in ASEAN to intervene in monetary policy variables so that uncontrolled deficits and fluctuations can achieve equilibrium in group of lower middle income in ASEAN.
\end{abstract}

Index Terms: Keywords: Current Account, Real Exchange Rate, Lower Middle Income, ASEAN.

\section{INTRODUCTION}

Each country not only produces for the needs of the domestic market but also for the needs of foreign markets, because the era of globalization requires the implementation of international trade [1], [2]. The implementation of international trade activities is related to export and import, which are summarized in the account of international trade called the current account. The condition of the current account is often unbalanced due to the interaction between exports and imports [3], [4]. International trade activities can result in a country more likely to export which results in a current account being a surplus because revenues are greater than expenditures or a country is more likely to import which results in a current account being a deficit because expenditure are greater than revenue [5].

The surplus is a good and desirable condition for each country in international trade activities. While the deficit is a bad condition that must be avoided by every country because it is a serious problem that disrupts economic stability for international trade. Every country is important to maintain its stability, because it is used as an indicator to assess the strength of the global economy in achieving global balance to improve economic performance [6].

Revised Manuscript Received on April 19, 2019.

Hasdi Aimon, Fakultas Ekonomi, Universitas Negeri Padang, Padang, Indonesia.

Sri Ulfa Sentosa, Fakultas Ekonomi, Universitas Negeri Padang, Padang, Indonesia.

Anggi Putri Kurniadi, Fakultas Ekonomi, Universitas Negeri Padang, Padang, Indonesia.
The most influential factor in the imbalance of the current account condition is real exchange rate fluctuations because transactions in international trade activities do not use domestic currency, but each country must use the real exchange rate [7]. The relationship between the two is depreciation which causes the price of exported products to be cheaper for importing countries, but when the country imports from other countries the price of imported products becomes more expensive, so depreciation has an impact on increasing exports and decreasing imports [8], [9].

On the other hand, the surplus and deficit is the basis of the appreciation and depreciation in a country, if exports are greater than imports, the condition will be surplus. Export payments require domestic currency, so an increase in export volumes will increase demand for domestic currencies, which results in an appreciation against the currencies of trading partner countries. Whereas if imports decline, it will reduce demand for the currencies of trading partner countries, so that their currencies will depreciate against the domestic currency [10], [11]. Based on this, the surplus will cause appreciation in the currency.

On the contrary, if the deficit will cause depreciation in the currency because large imports require the currency of a large trading partner country. Based on this explanation, it is important to analyze the causality relationship for these two variables. The current account imbalance and the real exchange rate fluctuations in ASEAN still experience imbalances, this occurs in group of lower middle income. The conditions are summarized in Fig. 1 and Fig. 2.

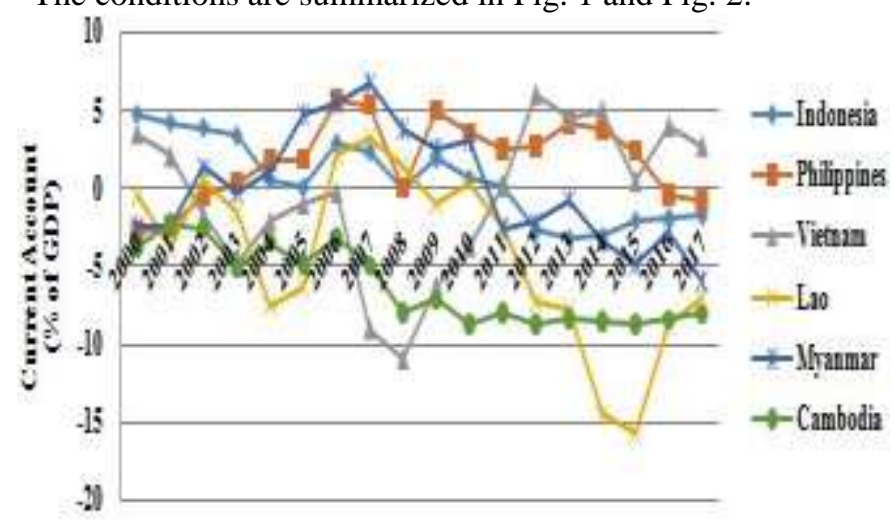

Fig. 1. Current Account Conditions in Group of Lower Middle Income in ASEAN. Source: Author Calculations.

Published By:

Blue Eyes Intelligence Engineering

\& Sciences Publication 


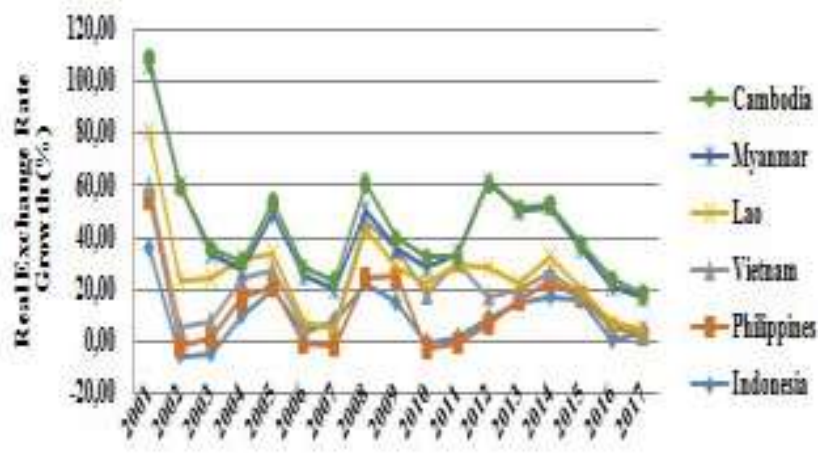

Fig. 2. Real Exchange Rate Growth Conditions in Group of Lower Middle Income in ASEAN. Source: Author Calculations.

Based on the information in Fig. 1, fluctuations occur every year, but over the past five years there have been ongoing deficits in Indonesia, Lao, Myanmar and Cambodia. However, there are also countries that have surpluses, but over time their conditions have declined, and they have even experienced deficits in the Philippines and Vietnam. While the information in Fig. 2 is that for all countries it has very varied and sharp fluctuations every year.Based on the explanation in Fig. 1 and Fig. 2 as a whole, the two problems are interesting to examine in international monetary economic studies because they provide information about the health of the economy in a country. Based on this, the authors are interested in examining the problem of imbalances and fluctuations for these problems in group of lower middle income in ASEAN from 2000 to 2017 .

\section{LITERATURE REVIEW}

Research conducted by previous researchers about the current account balance shows the influences among them [12] analyze in Pakistan that an increase in foreign direct Investment cause a sustained deficit. [13] investigating in developing countries that economic growth, economic openness, and appreciation of real exchange rates cause conditions to deteriorate, while output and interest rates cause conditions to improve. [14] also investigated in developing countries that the financial development and net foreign assets which caused a surplus and openness of the economy caused a deficit. [15], [16] investigating in developing countries in ASIA that government spending and economic openness are causing deficits. [17] investigate in Malawian that net foreign assets increase surplus, while openness of the economy, real exchange rate, and inflation causes a deficit. [18], [19] investigate in developing countries that government spending and inflation cause deficits. [20] analyze conditions between developing countries in Europe and developing countries in Asia that financial development and economic growth cause conditions to improve, while inflation and real exchange rates cause conditions to deteriorate. [21] investigating in the 10 new EU member states that economic growth increases the surplus, while foreign direct investment, inflation and government spending cause deficits. [22] investigate new EU members that appreciation in real exchange rates causes conditions to deteriorate. [23] analyze in Turkey that the real exchange rate and economic openness cause conditions to deteriorate. [24] investigating at FYROM that financial development, government spending and trade conditions caused conditions to improve, while economic openness caused conditions to deteriorate.

Research conducted by previous researchers about the real exchange rate shows the influences among them [25] analyze in Turkey that government spending, the money supply, and economic openness that causes appreciation, while foreign direct investment, economic growth causes depreciation. [26] investigating in Sudan that the money supply, inflation, economic openness result in depreciation. [27] investigating in India that economic growth and foreign direct investment have a positive effect, while inflation, interest rates and current transactions have a negative effect. [28] investigate in Croatia that inflation, the money supply, and direct foreign investment are causing depreciation.

The literature review used in this study combines the results of research conducted by previous researchers about the determinants of current account and real exchange rates. The difference is that the previous researchers only investigated the determinants, while the research we conducted examined the causality and determinants for both of these in group of lower middle income in ASEAN by using simultaneous equation models.

\section{METHODOLOGY}

\section{A. Type and Sources of Data}

The study used secondary data sources covering the time series ranged from 2000 up to 2017 and cross sections 6 countries (Indonesia, Philippines, Vietnam, Lao, Myanmar, and Cambodia). Data are collected from World Bank.

The data set includes Current Account ( $\left.\mathrm{Y}_{1}\right)$, Real Exchange Rate $\left(\mathrm{Y}_{2}\right)$, Financial Development $\left(\mathrm{X}_{1}\right)$, Government Spending $\left(\mathrm{X}_{2}\right)$, Economic Growth $\left(\mathrm{X}_{3}\right)$, Inflation $\left(\mathrm{X}_{4}\right)$, Economic Openness $\left(\mathrm{X}_{5}\right)$, Foreign Direct Investment $\left(\mathrm{X}_{6}\right)$, Money Supply $\left(\mathrm{X}_{7}\right)$, and Interest Rate $\left(\mathrm{X}_{8}\right)$. The information is summarized in the following Table I.

Table I. Description Variables and Sources of Data Description

Current Account The sum of net exports of World

$\left(\mathrm{Y}_{1}\right) \quad$ goods and services, net Bank primary income, and net secondary income (Percent of GDP)

Real Exchange Rate The relative price of the two $\left(\mathrm{Y}_{2}\right)$ countries currencies in trading goods and services (Local Currency Unit)

Financial

Development $\left(\mathrm{X}_{1}\right)$

Government

Spending $\left(\mathrm{X}_{2}\right)$

Economic Growth

$\left(\mathrm{X}_{3}\right)$ Proxy of money supply to GDP (Percent of GDP)

General government final consumption expenditure (Percent of GDP)

Annual percentage growth rate of GDP at market prices based on constant 2010 U.S. dollars (Percent)
World

Bank

\section{World}

Bank

World

Bank

World

Bank 
Inflation $\left(\mathrm{X}_{4}\right)$

Economic Openness $\left(\mathrm{X}_{5}\right)$ Foreign Direct Investment $\left(\mathrm{X}_{6}\right)$

$\begin{array}{lr}\text { Money } & \text { Supply } \\ \left(\mathrm{X}_{7}\right) & \\ \text { Interest } & \text { Rate } \\ \left(\mathrm{X}_{8}\right) & \end{array}$

The annual percentage change in the cost to the average consumer of acquiring a basket of goods and services (Percent)

Ratio of export plus import to GDP (Percent of GDP)

The amount of net investment inflows from equity capital, income reinvestment, other long-term capital, and shortterm capital (Percent of GDP) Broad money M2 (Local Currency Unit)

Interest rate spread lending rate minus deposit rate (Percent)

\section{B. Selection of the Best Model Panel Data}

The selection of the best model in panel data is to choose the most appropriate model used in estimating panel data, which consists of; First, the Chow Test to choose the Common Effect Model or Fixed Effect Model $\left(\mathrm{H}_{0}=\mathrm{CEM}\right.$ and $\mathrm{H}_{1}=\mathrm{FEM}$ ); Second, the Hausman Test to choose Fixed Effect Model or Random Effect Model $\left(\mathrm{H}_{0}=\mathrm{REM}\right.$ and $\mathrm{H}_{1}=$ FEM); Third, Lagrange Multiplier test to choose Random Effect Model or Common Effect Model $\left(\mathrm{H}_{0}=\mathrm{CEM}\right.$ and $\mathrm{H}_{1}$ $=$ REM). If the estimation result in the Chow test is FEM, then there is no need to do a Lagrange Multiplier test.

\section{Simultaneous Equation Models}

The simultaneous equation model is an equation where the dependent variable in one or more equations is also an independent variable in several other equations so that in a system the equation of a variable also has two roles, namely as the dependent variable and the independent variable. In the simultaneous equation model consists of endogenous variables are independent variables in the system of simultaneous equations whose values are determined in the system of equations and exogenous variables are variables whose values are determined outside the system of equations. The conceptual framework is summarized in Fig. 3.

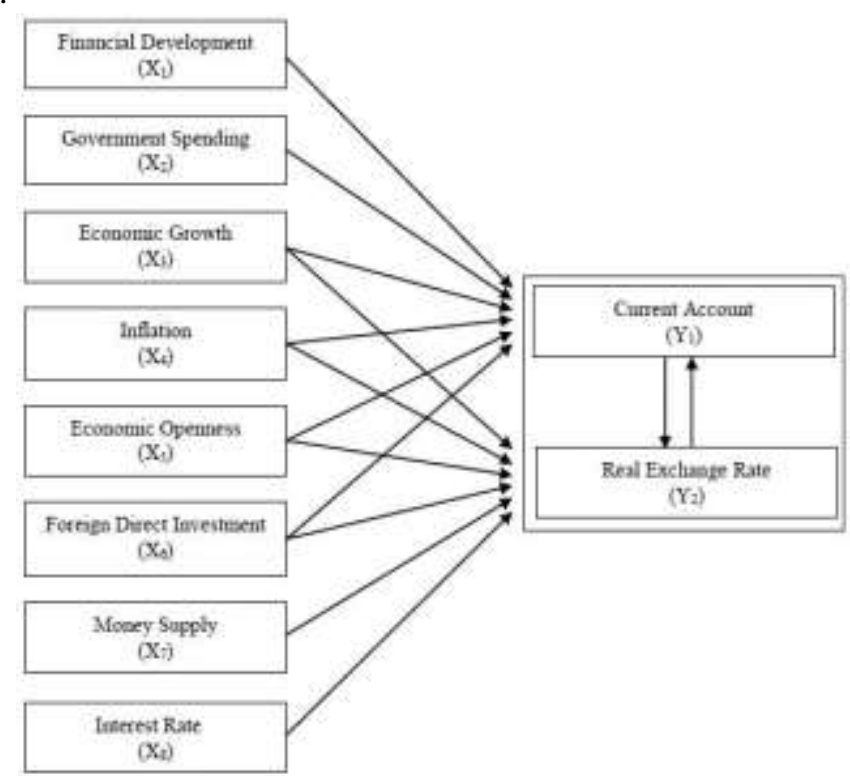

Fig. 3. Conceptual Framework
Based on the conceptual framework in Fig. 3, an econometric model can be written for simultaneous equation models:

$$
\begin{aligned}
Y_{1 \text { it }}= & \alpha_{0}+\alpha_{1} X_{1 \text { it }}+\alpha_{2} X_{2 i t}+\alpha_{3} X_{3 i t}+\alpha_{4} X_{4 i t} \\
& +\alpha_{5} X_{5 i t}+\alpha_{6} X_{6 i t}+\alpha_{7} \log \left(Y_{2}\right)_{\text {it }}+\varepsilon_{1 \text { it }}
\end{aligned}
$$

$$
\begin{aligned}
\log \left(\mathrm{Y}_{2}\right)_{\mathrm{it}}= & \beta_{0}+\beta_{1} \mathrm{X}_{3 \mathrm{it}}+\beta_{2} \mathrm{X}_{4 \mathrm{it}}+\beta_{3} \mathrm{X}_{5 \mathrm{it}}+\beta_{4} \mathrm{X}_{6 \mathrm{it}} \\
& +\beta_{5} \log \left(\mathrm{X}_{7}\right)_{\mathrm{it}}+\beta_{6} \mathrm{X}_{8 \mathrm{it}}+\beta_{7} \mathrm{Y}_{1 \mathrm{it}}+\varepsilon_{2 \mathrm{it}}
\end{aligned}
$$

Where,

$\mathrm{Y}_{1}$ and $\mathrm{Y}_{2} \quad$ = endogenous variables

$\mathrm{X}_{1}-\mathrm{X}_{8} \quad$ = exogenous variables

$\alpha_{0}$ and $\beta_{0} \quad=$ constants

$\alpha_{1}-\beta_{7} \quad=$ structural parameter

$\mathrm{i} \quad=$ countries (Indonesia,

Philippines, Vietnam, Lao, Myanmar, and Cambodia)

$$
\begin{array}{ll}
\mathrm{t} & =\text { year }(2000-2017) \\
\varepsilon_{1} \text { and } \varepsilon_{2} & =\text { residual }
\end{array}
$$

\section{Rules for Identifying Simultaneous Equation System}

Rules for identifying simultaneous equation systems; First, if $\mathrm{K}-\mathrm{k}<\mathrm{m}-1$, the equation is under identified, parameter estimation cannot be carried out, the solution is to form another model; Second, if $\mathrm{K}-\mathrm{k}=\mathrm{m}-1$, the equation has just identified, the parameter estimation technique is ILS (Indirect Least Square); Third, if $\mathrm{K}-\mathrm{k}>\mathrm{m}-1$, the equation is over identified, the parameter estimation technique is 2SLS (Two Stages Least Square).

\section{E. Analytical Method}

The first step is to identify each equation simultaneous. The second step is to do parameter estimation of the CEM, FEM, and REM use panel data estimation techniques in the first step. Then compare between CEM, FEM, and REM, which is more appropriate to declare panel data simultaneity. The third step after the model selected, perform; coefficient of determination $\left(\mathrm{R}^{2}\right)$ to measure the proportion of total variation on the dependent variable which can be explained by the independent variable, if $\mathrm{R}^{2}=$ 0 or close to zero, then there is no influence between independent variables on the dependent variable, if $\mathrm{R}^{2}=1$ or close to one, then there is a significant effect between the independent variables on the dependent variable; parameter significance tests simultaneously (F Test) to test the coefficients in the model whether the independent variables together have an influence on the dependent variable $\left(\mathrm{H}_{0}: \alpha\right.$ $=0$ and $\mathrm{H}_{1}$ : at least one value $\alpha \neq 0$ or collectively variables independent has a significant effect on the model); and significance test individual parameters ( $t$ Test) for the selected model to test the significance of the model coefficients individually on the dependent variable by assuming that other variables are constant $\left(\mathrm{H}_{0}=\right.$ independent variables not significant to the dependent variable and $\mathrm{H}_{1}=$ independent variables significant to the dependent variable). 


\section{RESULTS}

\section{A. Simultaneous Equation System}

The identification of simultaneous equation system is summarized in Table II.

Table II. Identification of Simultaneous Equation System

\section{System Structural Structural} Equations Equations (1)

$\begin{array}{llll}\begin{array}{l}\text { Endogenous } \\ \text { Variable }\end{array} & 2 & 1 & 1 \\ \begin{array}{l}\text { Exogenous } \\ \text { Variable }\end{array} & 8 & 6 & 6 \\ \begin{array}{l}\text { Identification } \\ \text { Estimation }\end{array} & \begin{array}{l}\text { over } \\ \text { identified }\end{array} & \begin{array}{l}\text { over } \\ \text { identified }\end{array} \\ \text { 2SLS } & \text { 2SLS }\end{array}$

Source: Author Calculation

Based on the information in Table 2 it can be concluded that the identification results are over identified so that the simultaneous equation model is estimated using the 2SLS (Two Stages Least Square) approach.

\section{B. Panel Data in the Simultaneous Equation Model}

The panel data estimation results for CEM in the simultaneous equation model are summarized in the following equation:

$$
\begin{aligned}
\mathrm{Y}_{1 \mathrm{it}}=1.789+0.061 \mathrm{X}_{1 \mathrm{it}}-0.299 \mathrm{X}_{2 \mathrm{it}}+0.144 \mathrm{X}_{3 \mathrm{it}} \\
+0.009 \mathrm{X}_{4 \mathrm{it}}-0.011 \mathrm{X}_{5 \mathrm{it}}-0.952 \mathrm{X}_{6 \mathrm{it}} \\
-0.052 \log \left(\mathrm{Y}_{2}\right)_{\mathrm{it}} \\
\log \left(\mathrm{Y}_{2}\right)_{\mathrm{it}}=-16.384+0.022 \mathrm{X}_{3 \mathrm{it}}+0.001 \mathrm{X}_{4 \mathrm{it}}+0.029 \mathrm{X}_{5 \mathrm{it}} \\
-0.478 \mathrm{X}_{6 \mathrm{it}}+0.677 \log \left(\mathrm{X}_{7}\right)_{\mathrm{it}}+0.142 \mathrm{X}_{8 \mathrm{it}} \\
-0.615 \mathrm{Y}_{1 \mathrm{it}}
\end{aligned}
$$

The panel data estimation results for FEM in the simultaneous equation model are summarized in the following equation:

$$
\begin{array}{rl}
\mathrm{Y}_{1 \mathrm{it}}=1 & .245+0.076 \mathrm{X}_{1 \mathrm{it}}-0.312 \mathrm{X}_{2 \mathrm{it}}+0.200 \mathrm{X}_{3 \mathrm{it}} \\
& -0.027 \mathrm{X}_{4 \mathrm{it}}-0.018 \mathrm{X}_{5 \mathrm{it}}-1.011 \mathrm{X}_{6 \mathrm{it}} \\
& -0.020 \log \left(\mathrm{Y}_{2}\right)_{\mathrm{it}} \\
\log \left(\mathrm{Y}_{2}\right)_{\mathrm{it}}= & -16.850+0.016 \mathrm{X}_{3 \mathrm{it}}-0.011 \mathrm{X}_{4 \mathrm{it}}+0.028 \mathrm{X}_{5 \mathrm{it}} \\
& -0.447 \mathrm{X}_{6 \mathrm{it}}+0.694 \log \left(\mathrm{X}_{7}\right)_{\mathrm{it}}+0.150 \mathrm{X}_{8 \mathrm{it}} \\
& -0.572 \mathrm{Y}_{1 \mathrm{it}}
\end{array}
$$

The panel data estimation results for REM in the simultaneous equation model are summarized in the following equation:

$$
\begin{aligned}
\mathrm{Y}_{1 \mathrm{it}}= & 1.790+0.061 \mathrm{X}_{1 \mathrm{it}}-0.299 \mathrm{X}_{2 \mathrm{it}}+0.144 \mathrm{X}_{3 \mathrm{it}} \\
& +0.009 \mathrm{X}_{4 \mathrm{it}}-0.011 \mathrm{X}_{5 \mathrm{it}}-0.952 \mathrm{X}_{6 \mathrm{it}} \\
& -0.053 \log \left(\mathrm{Y}_{2}\right)_{\mathrm{it}} \\
\log \left(\mathrm{Y}_{2}\right)_{\mathrm{it}}= & -16.384+0.022 \mathrm{X}_{3 \mathrm{it}}+0.001 \mathrm{X}_{4 \mathrm{it}}+0.029 \mathrm{X}_{5 \mathrm{it}} \\
& -0.478 \mathrm{X}_{6 \mathrm{it}}+0.678 \log \left(\mathrm{X}_{7}\right)_{\mathrm{it}}+0.143 \mathrm{X}_{8 \mathrm{it}} \\
& -0.615 \mathrm{Y}_{1 \mathrm{it}}
\end{aligned}
$$

\section{Chow Test}

The Chow Test used for selecting the CEM or FEM can be determined from the results of the Chow Test which are summarized in Table III.

$\begin{array}{lcl} & \begin{array}{c}\text { Table III. Chow Test } \\ \text { F Statistics }\end{array} & \text { Sig. } \\ & 15.689876 & 0.0410 \\ \text { Equation (1) } & 30.042213 & 0.0000 \\ \text { Equation (2) } & \text { Source: Author Calculations. } & \end{array}$

Based on the Chow Test results in Table III, the probability significance in equation 1 is 0.0410 and the probability in equation 2 is 0.0000 , where the second value of the probability is small than $\alpha=0.05$, and the value of $F$ statistics in equation 1 and equation 2 is greater than the value of $\mathrm{F}$ table is 2.03, then $\mathrm{H}_{0}$ is rejected and $\mathrm{H}_{1}$ is accepted, so FEM is better to use.

\section{Hausman Test}

The Hausman Test used for selecting the REM or FEM can be determined from the results of the Hausman Test which are summarized in Table IV.

Table IV. Hausman Test

\section{Chi-Sq Statistics Sig}

Equation (1)

19.734977

Equation (2) 17.943336
Source: Author Calculations.

0.0062

Based on the Hausman Test results in Table IV, the probability significance in equation 1 is 0.0062 and the probability significance in equation 2 is 0.0169 , where the second value of the probability is small than $\alpha=0.05$, and Chi-Sq statistics in equation 1 and equation 2 is greater than the Chi-Sq table is 16.01 , then $\mathrm{H}_{0}$ is rejected and $\mathrm{H}_{1}$ is accepted, so FEM is better to use.

\section{E. Coefficient of Determination $\left(R^{2}\right)$}

The calculation results of the coefficient of determination $\left(\mathrm{R}^{2}\right)$ are summarized in Table $\mathrm{V}$.

Table V. Coefficient of Determination (R2) Coefficient of Determination $\left(\mathbf{R}^{2}\right)$

\section{Equation (1) $\quad 0.651011$}

Equation (2) $\quad 0.589283$

Source: Author Calculations.

Based on the results of panel data regression on the simultaneous equation model in Table $\mathrm{V}$ for equation 1 the $\mathrm{R}^{2}$ value is 0.651011, which means that the Current Account $\left(\mathrm{Y}_{1}\right)$ in lower middle income countries in ASEAN can be explained by Financial Development $\left(\mathrm{X}_{1}\right)$, Government Spending $\left(\mathrm{X}_{2}\right)$, Economic Growth $\left(\mathrm{X}_{3}\right)$, Inflation $\left(\mathrm{X}_{4}\right)$, Economic Openness $\left(\mathrm{X}_{5}\right)$, Foreign Direct Investment $\left(\mathrm{X}_{6}\right)$, and Real Exchange Rate $\left(\mathrm{Y}_{2}\right)$ with a contribution of $65.1011 \%$, while the remaining $34.8989 \%$ is explained by other variables outside the model. While for equation 2 the $\mathrm{R}^{2}$ value is 0.589283 , which means that the Real Exchange Rate $\left(\mathrm{Y}_{2}\right)$ in lower middle income countries in ASEAN can be explained by Economic Growth $\left(\mathrm{X}_{3}\right)$, Inflation $\left(\mathrm{X}_{4}\right)$, Economic Openness $\left(\mathrm{X}_{5}\right)$, Foreign Direct Investment $\left(\mathrm{X}_{6}\right)$, Money Supply $\left(\mathrm{X}_{7}\right)$, Interest Rate $\left(\mathrm{X}_{8}\right)$, and Current Account $\left(\mathrm{Y}_{1}\right)$ with a contribution of $58.9283 \% \%$, while the remaining $41.0717 \%$ is explained by other variables outside the model. 


\section{F. F Test} VI.

The calculation results of $F$ Test are summarized in Table

\begin{tabular}{lll} 
& \multicolumn{2}{c}{ Table VI. F Test } \\
& F Statistics & Sig. \\
Equation (1) & 6.492662 & 0.0000 \\
Equation (2) & 8.541237 & 0.0000
\end{tabular}

Source: Author Calculations.

Based on Table VI for equation 1 is F statistics 15.15565 is greater than $\mathrm{F}$ table 2.03 , this can also be seen from the probability $\mathrm{F}$ statistics 0.0000 which is smaller than the value of $\alpha=0.05$, then $\mathrm{H}_{0}$ is rejected and $\mathrm{H}_{1}$ is accepted that together with Financial Development $\left(\mathrm{X}_{1}\right)$, Government Spending $\left(\mathrm{X}_{2}\right)$, Economic Growth $\left(\mathrm{X}_{3}\right)$, Inflation $\left(\mathrm{X}_{4}\right)$, Economic Openness $\left(\mathrm{X}_{5}\right)$, Foreign Direct Investment $\left(\mathrm{X}_{6}\right)$, and Real Exchange Rate $\left(\mathrm{Y}_{2}\right)$ significantly influence Current Account $\left(\mathrm{Y}_{1}\right)$ in lower middle income countries in ASEAN. While for equation 2 is $\mathrm{F}$ statistics 8.541237 is greater than $\mathrm{F}$ table 2.03 , this can also be seen from the probability $\mathrm{F}$ statistics 0.0000 which is smaller than the value of $\alpha=0.05$, then $\mathrm{H}_{0}$ is rejected and $\mathrm{H}_{1}$ is accepted that together with Economic Growth $\left(\mathrm{X}_{3}\right)$, Inflation $\left(\mathrm{X}_{4}\right)$, Economic Openness $\left(\mathrm{X}_{5}\right)$, Foreign Direct Investment $\left(\mathrm{X}_{6}\right)$, Money Supply $\left(\mathrm{X}_{7}\right)$, Interest Rate $\left(\mathrm{X}_{8}\right)$, and Current Account $\left(\mathrm{Y}_{1}\right)$ significantly influence Real Exchange Rate $\left(\mathrm{Y}_{2}\right)$ in lower middle income countries in ASEAN.

\section{G. $t$ Test}

The results of the calculation of the t test for equation 1 are summarized in Table VII.

\begin{tabular}{lcccc}
\multicolumn{5}{c}{ Table VII. t Test for Equation 1 } \\
eariabl & \multicolumn{1}{c}{ Coefficie } & \multicolumn{1}{c}{$\mathbf{t}$} & Prob. \\
& & nt & Statistics & \\
$\mathrm{X}_{1}$ & 0.075972 & 3.247131 & 0.0017 \\
$\mathrm{X}_{2}$ & -0.311933 & -2.644762 & 0.0098 \\
$\mathrm{X}_{3}$ & 0.200000 & 1.035497 & 0.3034 \\
$\mathrm{X}_{4}$ & -0.026604 & -0.541781 & 0.5894 \\
$\mathrm{X}_{5}$ & -0.017828 & -0.908346 & 0.3663 \\
$\mathrm{X}_{6}$ & -1.010641 & -6.879205 & 0.0000 \\
$\log \left(\mathrm{Y}_{2}\right)$ & & 0.077093 & 0.9387 \\
& & &
\end{tabular}

Source: Author Calculations.

Based on Table VII that the conclusion of the $t$ Test is Financial Development $\left(\mathrm{X}_{1}\right)$ individually has a positive and significant effect on Current Account $\left(\mathrm{Y}_{1}\right)$ because $\mathrm{t}$ statistics is 3.247131 which is greater than t table 1.98397 and the probability is 0.0017 which is smaller than the probability $\alpha=0.05$ which is consistent with [29], [30]. Further, Government Spending $\left(\mathrm{X}_{2}\right)$ and Foreign Direct Investment $\left(\mathrm{X}_{6}\right)$ individually have a negative significant effect on Current Account ( $\left.\mathrm{Y}_{1}\right)$ because t statistics for these two variables in sequence are -2.644762 and -6.879205 which are smaller than table -1.98397 and the probability for the two variables in sequence are 0.0098 and 0.0000 which are smaller than the probability $\alpha=0.05$ which is consistent with [31], [32].

The results of the calculation of the $t$ test for equation 2 are summarized in Table VIII.
Table VIII. $\mathbf{t}$ Test for Equation 2

$\begin{array}{llll}\text { Variable } & \text { Coefficient } & \text { t Statistics } & \text { Prob. } \\ \mathrm{X}_{3} & 0.015679 & 0.126885 & 0.8993 \\ \mathrm{X}_{4} & -0.010643 & -0.345806 & 0.7304 \\ \mathrm{X}_{5} & 0.028239 & 4.410889 & 0.0000 \\ \mathrm{X}_{6} & -0.447008 & -2.092789 & 0.0394 \\ \log \left(\mathrm{X}_{7}\right) & 0.694027 & 4.993516 & 0.0000 \\ \mathrm{X}_{8} & 0.149865 & 3.698339 & 0.0004 \\ \mathrm{Y}_{1} & -0.572202 & -3.208011 & 0.0019\end{array}$

Source: Author Calculations.

Based on Table VIII that the conclusion of the $t$ Test is Economic Openness $\left(\mathrm{X}_{5}\right)$, Money Supply $\left(\mathrm{X}_{7}\right)$, and Interest Rates $\left(\mathrm{X}_{8}\right)$ individually have a positive and significant effect on Real Exchange Rate $\left(\mathrm{Y}_{2}\right)$ because $\mathrm{t}$ statistics in sequence are 4.410889, 4.993516, and 3.698339 which are greater than $\mathrm{t}$ table 1.98397 and the probability for the three variables in sequence are $0.0000,0.0000,0.0004$ which are smaller than the probability $\alpha=0.05$ which is consistent with [3], [27]. Further, Government Spending $\left(\mathrm{X}_{2}\right)$ and Foreign Direct Investment $\left(\mathrm{X}_{6}\right)$ individually have a negative significant effect on Real Exchange Rate $\left(\mathrm{Y}_{2}\right)$ because $\mathrm{t}$ statistics for these two variables in sequance are -2.644762 and -6.879205 which are smaller than t table -1.98397 and the probability for the two variables in sequance are 0.0098 and 0.0000 which are smaller than the probability $\alpha=0.05$ which is consistent with [33], [34].

\section{CONCLUSION}

This study uses simultaneous equation model to analyze the causality relationship between the current account and real exchange rate and its determinants in group of lower middle income in ASEAN with various macroeconomic indicators that influence it. Based on the results of the study that it should be a serious concern for policymakers and governments in ASEAN group of lower middle income must carefully handle the deficit so that the balance of the current account and the conditions of real exchange rate can be achieved through increasing exports and decreasing imports so that conditions is not sustainable. In addition, the government also needs to make proactive policies to stabilize the problem of real exchange rate imbalances in group of lower middle income in ASEAN through controlling the excessive rate of appreciation of the domestic currency through measured intervention policies from the central bank. The policy can be carried out is to keep in mind the stability of exchange rate of the domestic currency. If its depreciates too high, a policy that can be done is to maintain the balance of demand and supply in the foreign exchange market, reducing excessive pressure on its. This can be achieved by minimizing speculative purchases, so that a stable domestic currency condition can minimize the imbalance of the current account in group of lower middle income in ASEAN. 


\section{ACKNOWLEDGMENT}

This study work is supported by SIMLITABMAS (Sistem Informasi Penelitian dan Pengabdian Kepada Mayarakat) RISTEKDIKTI.

\section{REFERENCES}

1. P. R. Krugman and M. Obstfeld, International Economics: Theory And Policy, 6th ed. Pearson Education Singapore Pvt Ltd, India, 2003.

2. B. H. Kim, H. G. Min, Y. S. Hwang, and J. A. McDonald, “Are Asian countries' current accounts sustainable? Deficits, even when associated with high investment, are not costless," J. Policy Model., vol. 31, no. 2, pp. 163-179, 2009.

3. E. Lau, A. Z. Baharumshah, and C. T. Haw, "Current account: Mean-reverting or random walk behavior?," Japan World Econ., vol. 18, no. 1, pp. 90-107, 2006.

4. Z. Tan, Y. Yao, and S. J. Wei, "Financial structure, corporate savings and current account imbalances," $J$. Int. Money Financ., vol. 54, pp. 142-167, 2015.

5. M. Lu, "Current account dynamics and optimal monetary Financ., vol. 5, no. 3, p. 299, 2012.

6. E. Vangjeli, S. Gerdhe, and M. Teneqexhi, "Current account balance in Albania and the influence of different factors on it," Int. J. Trade Glob. Mark., vol. 5, no. 3/4,

7. O. Gervais, L. Schembri, and L. Suchanek, "Current account dynamics, real exchange rate adjustment, and the exchange rate regime in emerging-market economies," $J$. Dev. Econ., vol. 119, pp. 86-99, 2016.

8. J. Madura, International Financial Management, 9th ed. Florida Atlantic University, 2011.

9. M. G. Arghyrou and G. Chortareas, Real exchange rates and current account imbalances in the Euro-area, no. 0. 2006.

10. F. Mochtar and Y. Affandi, "Current Account and Real Exchange Rate Dynamics in Indonesia," Econ. Financ. Indones., vol. 61, no. 2, p. 83, 2018 .

11. D. Romelli and E. Vasconcelos, "Current Account and Real Exchange Rate changes: the impact of Trade Openness," Eur. Econ. Rev., pp. 1-25, 2013.

12. A. Salman, "Empirical Analysis Of The Impact Of Fdi On Pakistan's Current Account Balance," vol. 2, pp. 143-156, 2009.

13. C. Calderón, A. Chong, and L. Zanforlin, "Current Determinants," Econ. Dev. Cult., vol. 56, no. 1, pp. 191221, 2007.

14. M. D. Chinn and E. S. Prasad, "Medium-term determinants of current accounts in industrial and developing countries: an empirical exploration," Int. Econ., vol. 59(1), pp. 47-46, 2003.

15. M. D. Chinn and H. Ito, "Global current account imbalances: American fiscal policy versus East Asian savings," Rev. Int. Econ., vol. 16, no. 3, pp. 479-498, 2008.

16. J. W. Gruber and S. B. Kamin, "Explaining the global pattern of current account imbalances," J. Int. Money Financ., vol. 26, no. 4, pp. 500-522, 2007.

17. O. Nkuna, "Sustainability of the Malawian current account deficit: Application of structural and solvency approaches," J. Econ. Int. Financ., vol. 5, no. 5, pp. 187198, 2013

18. L. Medina, J. Prat, and A. Thomas, "Current Account Balance Estimates for Emerging Market Economies," IMF Work. Pap., 2010.

19. M. Bussière, M. Fratzscher, and G. J. Müller, "Current account dynamics in OECD and EU acceding countries policy in a two-country economy," Int. J. Monet. Econ. p. 235, 2012. Account Deficits in Africa: Stylized Facts and Basic

an intertemporal approach," 311, 2004.

20. S. Herrmann and A. Winkle, "Real convergence, financial markets and the current account Emerging Europe versus emerging Asi," 2009.

21. J. Rahman, "Current Account Developments in New Member States of the European Union: Equilibrium, Excess, and EU-Phoria," IMF Work. Pap., vol. 08, no. 92, p. 1, 2008.

22. P. Zanghieri, "Current Accounts Dynamics in new EU members: Sustainability and Policy Issues,” 2004.

23. F. Kayikçi, "Determinants of the current account balance in Turkey: Vector auto regression ( VAR ) approach," African J. Bus. Manag., vol. 6, no. 17, pp. 5725-5736, 2012.

24. L. Sadiku, M. Fetahi-Vehapi, M. Sadiku, and N. Berisha, "The Persistence and Determinants of Current Account Deficit of FYROM: An Empirical Analysis," Procedia Econ. Financ., vol. 33, no. 15, pp. 90-102, 2015.

25. Z. Kilicarslan, "Determinants of exchange rate volatility: empirical evidence for Turkey," Pressacademia, vol. 5, no. 2, pp. 204-213, 2018.

26. K. E. Elfaki, "Determinants of Exchange Rate Stability in Sudan ( 1991-2016 )," Int. Jorunal Econ. Financ. Issues, vol. 8, no. 2, pp. 33-39, 2018.

27. A. Mirchandani, "Analysis of Macroeconomic Determinants of Exchange Rate Volatility in India," Int. J. Econ. Finacial Issues, vol. 3, no. 1, pp. 172-179, 2013.

28. B. Manuel and I. Kersan-Skabic, "The determinants of exchange rate in South Africa," East. J. Eur. Stud., vol. 7, no. 1, p. 2016, 2016.

29. J. B. Gossé and F. Serranito, "Long-run determinants of current accounts in OECD countries: Lessons for intraEuropean imbalances," Econ. Model., vol. 38, pp. 451462, 2014.

30. A. Insel and B. Bulvarı, "Excessiveness of Current Account Deficits in Turkey," Int. J. Econ. Perspect., vol. 7, no. 4, pp. 11-21, 2013.

31. M. A. Wadud and S. M. A. Rahman, "SUSTAINABILITY OF THE CURRENT ACCOUNT IN BANGLADESH : AN INTERTEMPORAL AND," $J$. Dev. Areas, vol. 49, no. 1, 2015.

32. C. Elgin and T. U. Kuzubas, "Current account balances and output volatility," Econ. Model., vol. 33, pp. 381387, 2013.

33. K. Mungule, The determinant of real exchange rate in Zambia, vol. 18, no. 146. 2004.

34. M. Immurana and A. Iddrisu, "The Determinants of the Real Exchange Rate in Ghana: A Focus on Inflation Using a Bound Test Approach The Determinants of the Real Exchange Rate in Ghana: A Focus on Inflation Using a Bound Test Approach . Department of Accounting Studies Education, Un," no. December 2016, 2014

\section{AUTHORS PROFILE}

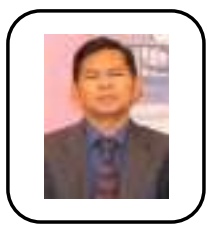

Prof. Dr. Hasdi Aimon, M.Si was born on Sulit Air on May 5, 1955. His education history is Bachelor's Degree obtained from the IKIP Padang in the Economic Education Program in 1985, Master's Degree obtained from the Unsyiah Banda Aceh in the Economics and Development Studies Program in 1997 Doctor's Degree obtained from the Unsyiah Banda Aceh in the Economics Science Program in 2006, and was officially designated as a Professor by the Republic of Indonesia Ministry of Research, Technology and Higher Education in 2016. Currently, he is a lecturer with a professorship at the Fakultas Ekonomi, Universitas Negeri Padang. His research focus areas are macroeconomics, 
microeconomics, international economics, and monetary economics. His research experience over the past three years is Determinants of Foreign Direct Investment in Indonesia; The Analysis of Current Account Balance System in Indonesia; The Management of Student's Pocket Money; Efficiency and Effectiveness of Governance Home Industry "Kerupuk Ubi Kamang” In Kamang Magek, West Sumatera; The Equilibrium Analysis of Consumption and Imports of Soybean in Indonesia. His international conference experience is Analysis of Economic Development in North Sumatra Province; Analysis and Prospect of Economic Growth and Income Inequality in West Sumatra Province; Environmental and Economic Value Studies In the Use of the Tomatoes Production Land; Analysis of the Relationship between Credit Rating and Foreign Direct Investment in Indonesia; The Economic Development Model in Supporting The Economy of Pariaman Regional Area; The Model of Productivity and Efficiency on Fish Catching Results in Coastal Fishermen City of Padang; The Equilibrium Analysis of Consumption and Imports of Soybean in Indonesia; The Equilibrium Analysis of Consumption and Imports of Soybean in Indonesia.

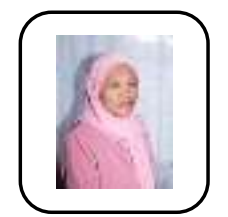

Dr. Dra. Sri Ulfa Sentosa, MS. was born on Bukittinggi on 02 Mei 1961. Her education history is Bachelor's Degree obtained from the IKIP Padang in the Economic Education Program in 1985, Master's Degree obtained from the IPB in the Rural Area Development Planning Program in 1992, and Doctor's Degree obtained from the UNPAD in Agricultural Economics Program in 2001. Currently, she is a lecturer at the Fakultas Ekonomi, Universitas Negeri Padang. Her research focus areas are macroeconomics, microeconomics, international economics, agricultural economics and monetary economics. Her research experience over the past two years is Entrepreneurial Competency Development with Training Program for Entrepreneur Small Scale Industry Sanjai Crackers in Bukittinggi City.

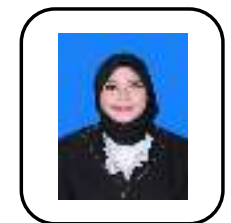

Anggi Putri Kurniadi, SE, ME. was born on Bukittinggi on 11 Januari 1995. Her education history is Bachelor's Degree obtained from the Universitas Negeri Padang in the Economic Development Program in 2017, Master's Degree obtained from the Universitas Negeri Padang in the Economic Science Program in 2019 and after obtaining a Masters of Economics, she continues her Doctoral Program at Universitas Negeri Padang in Environmental and Development Studies in 2019. Her research focus areas are macroeconomics, international economics, and monetary economics. Her achievements have been the best graduates at the graduation of university level bachelor's programs in 2017 and the best graduates at the graduation of university level master's programs in 2019. Her research experience over the past two years is on the Sustainability of Current Account Deficits in Indonesia: Error Correction Mechanism Approach; The Analysis of Current Account Balance System in Indonesia; Determinants of Current Account in ASEAN: Lower Middle Income Countries; The Exsistence of Economic Openness and the Strength of Real Exchange Rate. 